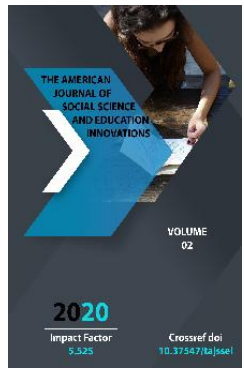

Journal Website: http://usajournalshub.c om/index,php/tajssei

Copyright: Original content from this work may be used under the terms of the creative commons attributes 4.0 licence.

\section{From The History Of Military Education In Turkestan}

\author{
Rozimova Yorqinoy Yuldashevna \\ Captain, Candidate Of Historical Sciences, Teacher Of The Department Of Humanities, \\ Academy Of The Armed Forces Of The Republic Of Uzbekistan, Tashkent, Uzbekistan
}

Abduraximova Dilfuzaxon Alievna

Associate Professor, Candidate Of Pedagogical Sciences, Department Of Humanities, Armed Forces Academy, Tashkent, Uzbekistan

\title{
ABSTRACT
}

This article provides information on the establishment of military education in Turkestan in the second half of the 19th century, in particular, the establishment of the Tashkent Cadet School on the basis of the Academy of the Armed Forces of the Republic of Uzbekistan and the development of military education.

\section{KEYWORDS}

Turkestan, Central Asia, cadet school, TSh (Tashkentskaya shkola), military education, platsdarm, governor-general, vice-unter officer.

\section{INTRODUCTION}

All the monuments and buildings we know today have their own deep and meaningful history in terms of appearance. Once upon a time it was built or founded by human hands and labor, intellect. Sometimes by looking for information and finding other new information, I became convinced once again that history is a very interesting science.
It is desirable that every citizen of the State, first of all, has a good knowledge of the history of the nation, people and national heroes, as well as sufficient information about the founders of the achievements of the state and society in their specialty. Therefore, it is the duty of every serviceman to study the history of the Tashkent Higher Military 
Command School, which will replace the Academy of the Armed Forces of the Republic of Uzbekistan, which is currently working closely with the armies of all developed countries to develop military education.

The economic, social, and political situation in the Central Asian khanates in the second half of the 19th century accelerated the realization of Russia's intention to subjugate Central Asia, which at that time was one of the most aggressive countries in the world and lagging behind European countries. This intention led to a military expedition to Central Asia in 1717, led by Bekovich-Cherkassky, to conquer the Khiva Khanate during the reign of Russian Emperor Peter I (1672-1725).

But this movement, and other subsequent military actions: including the military march led by Perovsky in 1839-40, also failed. During the first half of the 18th and 19th centuries, the Russian government carried out Peter I's wishes, subjugated the Kipchak steppes, and built military fortifications there. [1].

During Russia's aggressive foreign policy, Central Asia had to act as a platsdarm in its military campaigns to China, India, Afghanistan, Iran, the seas in the south, and their access to the ocean through which to expand the empire in the future.

\section{MATERIALS AND METHODS}

It should also be noted that the interest of tsarism in Turkestan is also associated with the desire to develop the vast underground resources of this country. At the same time, in the middle of the 19th century, the interests of Russia and Britain clashed in Central Asia. This led Russia to develop a plan for the conquest of the Central Asian khanates and to accelerate military campaigns [2].
The invasions of the Russian Empire to Central Asia, which began in the summer of 1852 , ended in June 1873 with the conquest of the Kokand Khanate, the Bukhara Emirate and the Khiva Khanate.

In 1867, the Governor-General of Turkestan was established. By the $90 \mathrm{~s}$ of the 19th century, the Governor-General of Turkestan was divided into five regions - Syrdarya, Fergana, Samarkand, Ettisuv, Caspian, regions into districts, districts into districts, $[2,3]$.

The Tsarist government, which had difficulty managing the region, even ceded the lands of the emirate on the left bank of the Amu Darya: Balkh, Mazar-i-Sharif, Shiberghan, Kunduz and other territories to Afghanistan under an agreement signed on September 28, 1873.

After the conquest of Turkestan, Tsarist Russia made extensive use of the military system to enslave the people of the region. However, the inability of officers sent to military service in Turkestan to adapt to the country's climatic conditions and to suffer from various diseases would have a negative impact on the constant combat readiness of the army, which is the mainstay of the Russian state in the country. Therefore, in a letter addressed to Tsar Kerensky, the Inspector General of Education of the Governor-General of Turkestan, the Russian officers proposed to open a special school for the training of children of officials born and raised in Turkestan, adapted to local conditions, and this was resolved. As a result, on June 1, 1899, in accordance with the order No. 179 of the Turkestan military department, the Tashkent Preparatory School for 100 students of the 2nd Orenburg Cadet School was established. Due to the fact that the school building under construction on the Salar Canal (now the 
Academy of the Armed Forces of the Republic of Uzbekistan) was not completed by the beginning of the school year, the study began in 1901 in the building of the temporary district engineering department. [4, 2].

The cadets are provided with uniforms and the letter "TSh" (Tashkentskaya shkola Tashkent school) is placed on the shoulder straps. [3].

\section{RESULT AND DISCUSSION}

Admission to the cadet school was much more limited. The students were admitted to the school with the personal consent of the Governor-General of the Turkestan Military District. Admission of indigenous peoples to the preparatory school was banned because the Tsarist government was afraid to recruit indigenous peoples for military service, giving them weapons. But despite the restrictions, the representatives of our people tried to send their children to military school. Those who were allowed to study were mostly the children of the upper class and officials in the service of the Russian government.

It should be noted that in 1900, Said Khudoyorkhan's grandson, Allayorbek, the second son of Muhammad Aminbek (since 1887, his first son, nine-year-old Said Nuriddinbek was allowed to study at the 2nd Orenburg Cadet Corps), Said Nazar, the son of police ensign Avodbaev. Mirbadalov (probably the son of Major-General Mirbadalov of the Khiva Khan's army, the genealogy of which is not specified in the archives), in 1902 the granddaughter of Major-General of the Russian Army Jurabek, daughter of Zinnat Beka, Toshpolatbek Yuldashbekov, in 1903 Nasridinbek Khakimbekovich, Said Umarbek Amrullabek, accepted for study [1].
Mirbadalov Mirsobir, Mirbadalov Miryokub, Mirbadalov Mirgazis, Kasimov Muzrob, Khusravbek Khudoyorkhonov, Khudoyorkhon Said Muhammad, Vafadarkhonov Orazgeldikhon Geldievich were among the students of the cadet corps in 1913/14 academic year.

Kasimov Muzrob Useynovich, who successfully completed the cadet corps, was promoted to the rank of vice-officer and in 1916 was assigned to study at the Nikolaev School of Military Engineers. Due to limited archival information, it was not possible to obtain complete information about other students. However, according to the memoirs of Lieutenant General Norkhodjaev Fayzulla Khodjaevich, a 1931 graduate of the Central Asian Military School (TSAU), Lieutenant General Mirbodalov, a graduate of the Central Asian Military School in the 1920s, learned from Khudoyorkhon Azamatbek Antonovich visitors [4]. This is the only evidence that the Uzbeks, who graduated from the self-training school, have reached different levels of military command. For candidates to enter the cadet corps, a competition is scheduled for May and an exam for August. Those who did not pass the exam in May were not put to the exam in August. Those admitted had to go through a preparatory as well as a seven-stage training course. The cadets take exams every year in Russian, French, German, arithmetic, drawing and calligraphy. The exams were taken by special jury members $[1,3]$.

Most of the cadets' free time is spent on sports and training in the skills they will need in life after military service. Tuition is paid, and the annual fee is 500 soums. At the same time, the sponsors also transferred money. For example, on December 8, 1900, the Emir of Bukhara Said Olimkhan sent a thousand soums to the school through his ambassador. 
During the First World War, the Tashkent Training School was renamed the Tashkent Military Academy and turned into a training center for qualified military personnel for the army.

Formed after the overthrow of the Russian tsar as a result of the February 1917 bourgeoisdemocratic revolution, the preparatory school was renamed the Tashkent Cadet Corps by the order of the Minister of War of the Provisional Government No. 13445 of April 26 this year. After the Bolshevik Party seized power in the country in 1917, on June 12, 1918, the school was renamed the Turkestan Soviet Commanders' Course. It was agreed that this day would be celebrated as the day the school was founded [2].

\section{CONCLUSION}

By analyzing the above data, the following can be concluded:

1. The courage, bravery, and intellectual maturity of Uzbek boys have long been directly linked to the courage and personal example of our ancestors in history. Those who wish to object to this invite us to study our rich history as well as our current achievements.

2. The fact that the military education system at the Tashkent Cadet School is the basis of the current system of education in higher military educational institutions of the Republic of Uzbekistan means that military education is well-organized and effective at the time.

3. Today, the graduates of the Tashkent Cadet School (Tashkent Higher Military Command School) serve in the army in various ranks and positions in many countries around the world, as well as receive state heroes and other state awards, which means that the prestige of this institution is very high.

4. The results of the study show that this school was one of the main military schools that trained highly qualified personnel for the wars that took place in different periods.

\section{REFERENCES}

1. Kochkarov, T.A. History of Turkestan: textbook / T.A. Kochkarov, F.S. Urinov, D.B. Botirov. - T .: O'qituvchi, 2012. - 480 p.

2. Sayfudinov N.E., History of Uzbekistan: textbook / N.E. Sayfudinov, G.R. Umarov, U.T. Turgunbaev - T .: O'qituvchi, 2011. - 390 p.

3. Madyorov, G.A., History of Martial Arts: Textbook / G.A. Madyorov, Yu.M. Safarov, I.I. Miravazov - T .: O'qituvchi, 2017. - 346 p.

4. Alimkulov, V.S. From the Great Silk Road to the Eurasian Transport Corridor / V.S. Alimkulov // International relations. Politics, economics, law. - 2002. - No. 1. - p. 16-21.

5. Nigmanov, A.A. History of improving military education in Tashkent Higher Military School / A.A. Nigmanov // Academy News. -2017. № 2. - p. 37-40.

6. 1001 words: Dictionary for learners of Old Uzbek script and language / Compilerauthor M.A. Abdulxayrov. - T .: Qomuslar Bosh tahririyati, 1991. - $96 \mathrm{p}$. 